\title{
PEMBINAAN PRESTASI CABANG OLAHRAGA BOLA VOLI DI KLUB BINA TARUNA KOTA SEMARANG TAHUN 2021
}

\author{
Matrik Sulton Andara ${ }^{1)}$, Yulia Ratimiasih ${ }^{2)}$, Maftukin Hudah ${ }^{3}$ \\ ${ }^{1}$ FPIPSKR, Universitas PGRI Semarang \\ Email: matrikandara@gmail.com \\ ${ }^{2}$ FPIPSKR, Universitas PGRI Semarang \\ Email: yuliaratimiasih@upgris.ac.id \\ ${ }^{3}$ FPIPSKR, Universitas PGRI Semarang \\ Email: maftukinhudah@upgris.ac.id
}

\begin{tabular}{l}
\hline Artikel Info \\
\hline Koresponden penulis: \\
Matrik Sulton Andara \\
Email: matrikandara@gmail.com \\
$\square$ Diterima 14 April 2021 \\
$\square$ Direview 11 Juli 2021 \\
$\square$ Disetujui 16 Juli 2021 \\
$\square$ Dipublikasi 17 Juli 2021
\end{tabular}

Kata Kunci:

Pembinaan Prestasi, Bola Voli, Bina Taruna

Keywords:

Achievement Coaching, Volleyball, Youth Development

\begin{abstract}
Abstrak
Penelitian ini berlatar belakang olahraga dapat dijadikan sebagai alat pengukur prestasi disetiap cabang olahraga. Tujuan penelitian ini untuk mengetahui bagaimana pembinaan prestasi cabang olahraga bola. Jenis penelitian ini deskriptif kualitatif. Tempat penelitian di klub bola voli Bina Taruna Semarang, subyek penelitian yaitu pengurus, pelatih dan atlet. Sumber data terdiri dari observasi, wawancara dan dokumentasi. Teknik analisis data yang digunakan dengan reduksi data, penyajian data dan penarikan simpulan. Penelitian ini menghasilkan bahwa klub Bina Taruna Semarang sudah terbentuk organisasi dan pengurusnya mengelola dengan baik. Pelatih sudah mempunyai lisensi pelatih. Para atlet mengikuti program latihan secara disiplin sesuai dengan ketentuan yang ada. Sarana dan prasarana sudah lengkap walau lapangan bola voli masih sistem sewa bulanan, program latihan dua atau tiga kali dalam seminggu, dukungan atau pendanaan dari iuran bulanan atlet dan orangtua, dalam mengikuti pertandingan mendapat prestasi kejuaran-kejuaraan. Kesimpulan dari penelitian pembinaan prestasi cabang olahraga bola voli di Klub Bina Taruna Semarang sudah baik dapat dilihat dari struktur organisasi sudah lengkap, pengurus saling bekerja sama untuk peningkatan klub, pelatih klub sudah memiliki pengalaman.
\end{abstract}

\begin{abstract}
This research has a sports background that can be used as a measure of achievement in each sport. The purpose of this study was to find out how to foster achievements in the sport of football. This type of research is descriptive qualitative. The place of research in the volleyball club Bina Taruna Semarang, the research subjects were administrators, coaches and athletes. Sources of data consist of observation, interviews and documentation. Data analysis techniques used are data reduction, data presentation and drawing conclusions. This research results that the Bina Taruna Semarang club has formed an organization and its management is well managed. The trainer already has a trainer license. Athletes follow training programs in a disciplined manner in accordance with existing regulations. The facilities and infrastructure are complete even though the volleyball field is still a monthly rental system, a training program two or three times a week, support or funding from the monthly contributions of athletes and parents, in participating in competitions that get achievements in competitions The conclusion from the research on the development of the volleyball sport in the Bina Taruna Semarang Club is good, it can be seen from the complete organizational structure, the management works together to improve the club, the club coach already has experience.
\end{abstract}




\section{PENDAHULUAN}

Olahraga bola voli merupakan olahraga yang dimainkan 6 orang dalam setiap regunya yang terdiri dari libero, spikers dengan memainkan bola maksimal 3 sentuhan dalam setiap permainannya. Baik putra maupun putri. Dalam setiap cabang olahraga terdapat aturan yang mengikat dalam setiap permainannya yang dilakukan oleh setiap induk oraganisasi olahraga salah satunya PBVSI baik peraturan perwasitan maupun peraturan pertandingan yang berlaku. (Yudiana \& Subroto. 2010). Pembinaan olahraga nasional di Indonesia dilakukan melalui beberapa jalur, yaitu :1) Sekolah (mulai dari sekolah dasar sampai dengan perguruan tinggi), 2) Induk organisasiorganisasi olahraga, 3) Organisasi olahraga professional, 4) Organisasi yang ada dalam masyarakat (Candrawati, 2018).

Pola pembinaan prestasi olahraga di diindonesia pada umumnya setiap Klub bola voli yang ada saat ini bersifat ekstra kurikuler dan dilakukan lewat kegiatan minat dan bakat yang Klub Olahraga (Mutohir.TC, 2012:2).

Jonasson (2013:11) menyatakan bahwa "sport means all forms of physical activity which, through casual or organised participation, aim at expressing or improving physical fitness and mental well being, forming social relationships or obtaining results in competition at all levels". Sedangkan Menurut (Jamalong, 2016) berpendapat bahwa" olahraga adalah budaya manusia, artinya tidak dapat disebut ada kegiatan olahraga apabila tidak ada faktor manusia yang berperan secara ragawi/pribadi melakukan aktivitas olahraga itu.

\section{Untuk mencapai pembinaaan} prestasi atlet yang tinggi terdapat beberapa kegiatan dasar yang dilakukan dalam prosesnya. Adapun kegiatan-kegiatan tersebut secara berurutan adalah sebagai berikut: 1) Pemassalan, 2) Pembibitan, 3) Pemandu bakat, 4) Pembinaan, 5) Sistem latihan Dengan adanya kecenderungan prestasi yang meningkat, maka untuk berprestasi dan bersaing dengan yang lainnya dalam kegiatan olahraga prestasi, harus dikembangkan kualitas fisik, teknik, fisiologis dan sosial yang dituntut cabang olahraga tersebut. Untuk itu diperlukan suatu program pembinaan prestasi yang terencana dan terarah serta dilaksanakan secara berkesinambungan (Herman Subardjah, 2011: 68). yang menyatakan bahwa, "Dalam lingkup olahraga prestasi, tujuannya adalah untuk menciptakan prestasi yang setinggitingginya. Artinya bahwa berbagai pihak seharusnya berupaya untuk mensinergikan hal-hal dominan yang berpengaruh terhadap peningkatan prestasi di bidang olahraga Kristiyanto (2012: 12).

Permainan bola voli adalah kegiatan permainan yang dilakukan secara beregu oleh 6 orang dalam setiap timnya. Lapangan bola voli berbentuk peresgi Panjang dengan 
luas dan lebar lapangan sama berkisar 9meter x 19meter. Dan dilengkapi dengan sarana prasarana yang lainnya seperti halnya Net, tiang net dengan ukuran antara putra dan putri berbeda. Sedangkan pengertian bola voli menurut Bachtiar, dkk (2019:23). Permainan bola voli adalah permainan beregu yang dimainkan oleh dua tim yang masing-masing regu terdiri dari 6 orang pemain di lapangan. Lapangan dibagi dua bagian yang sama dengan sebuah garis tengah yang di atasnya dibentangkan net dengan ukuran tertentu. Sedangkan pengertian bola voli menurut Bachtiar, dkk (2019:23), sedangkan Permainan bola voli merupakan permainan yang dilakukan oleh dua tim yang masing-masing tim berjumlah 6 orang pemain. Setiap pemain memiliki keterampilan khusus yakni sebagai pemukul, pengumpan, dan libero. (Suharno HP 2010).

Pembinaan prestasi untuk cabang olahraga dapat dilakukan secara berjenjang, hal itu sependapat dengan yang dikemukakan oleh (Ateng A, 2013) bahwa Sistem pembinaan berdasarkan piramida adalah suatu pembinaan yang berjenjang dari lapisan bawah (pemassalan), kemudian dilanjutkan secara berkesinambungan ke lapisan tengah (pembibitan), terus berjenjang ke atas kepuncak piramida (pembinaan prestasi). Kondisi fisik secara umum terdiri dari: daya tahan (Endurance), kekuatan (Strength), daya ledak (Explosive Power), kecepatan (Speed), kelenturan (Fleksibility), kelincahan (agility), keseimbangan (Balance), dan koordinasi (Coordination). Heri Amin (2020:266). Jika kita lihat dari usia, hal tersebut dapat digolon gkan menjadi beberapa tingkatan yang ada dalam sistem piramida tersebut meliputi: 1) tingkat pemassalan adalah untuk atlet pemula, usia 12 tahun dan pra junior sampai dengan usia 16 tahun, 2) jenjang pembibitan adalah untuk atlet-atlet senior di atas 19 tahun.

\section{METODE PENELITIAN}

Pendekatan yang dilakukan dalam penelitian ini adalah pendekatan kualitatif. dalam penelitian ini difokuskan pada Pembinaan Prestasi Klub Bola Voli Bina Taruna Semarang. Sumber data didapatkan dari hasil observasi, wawancara dan dokumentasi. Dalam metode pengumpulan data dilakukan dengan cara wawancara, observasi dan dokumentasi, observasi obyek penelitian untuk informasi yang dibutuhkan. Peneliti menggunakan dua teknik pengecekan kredibilitas data dan triangulasi data. Teknik analisis data yang digunakan yaitu reduksi data, penyajian data, dan penarikan kesimpulan.

Secara umum terdapat empat macam teknik dalam pengumpulan data hasil penelitian, yaitu observasi, wawancara, dokumentasi, dan gabungan / triangulasi (Sugiyono, 2014:305-306). Sedangkan menurut (Moleong, 2010:324) Ada empat 
kriteria yang digunakan untuk memeriksa tentang keabsahan data, yaitu derajat kepercayaan (credibility), keteralihan (transferability), kebergantungan

(dependability), dan kepastian (confirmabilit.).

\section{HASIL DAN PEMBAHASAN}

Dari hasil penelitian pada klub Bina Taruna Semarang diperoleh melalui wawancara sebagai berikut:

1. Organisasi

Hasil wawancara dengan pengurus bahwa klub bola voli Bina Taruna Semarang sudah terbentuk organisasi dan kepengurusannya sudah lengkap dimana ada ketua umum, sekertaris, bendahara, bidang ketua harian, bidang kepelatih, bidang pendanaan dan bidang umum. Pengurus menjalankan tugasnya sesuai bidangnya masing-masing dan saling kerjasama untuk meningkatkan klub bola voli. Dalam pemilihan pengurus klub tidak ada kriteria khusus, pemilihan pengurus berdasarkan rapat dengan pengurus, pelatih, dan orang tua atlet.

\section{Pelatih}

Dalam wawancara tentang pelatih, dalam perekrutan pelatih yang diutamakan jebolan atlet-atlet binaan dari klub Bina Taruna Semarang yang masih loyal dengan olahraga bola voli. Pelatih klub Bina Taruna Semarang mempunyai lisensi baik Provinsi maupun Nasional, karena akan berpengaruh ketika mengikuti pertandingan antar kota atau antar klub. Dalam wawancara terdapat data ada pelatih di klub Bina Taruna menekuni bidang pelatihan mulai tahun 2011 dengan lisensi Provinsi.

3. Atlet

Dari hasil wawancara tentang atlet di klub Bina Taruna Semarang, bahwa dalam perekrutan atlet tidak ada kriteria khusus, anak-anak mendaftarkan diri sebagai atlet di klub Bina Taruna, kemudian dikelompokkan untuk berlatih dan mengembangkan prestasi bola voli. Para atlet di didik disiplin untuk mengikuti jadwal dan program latihan yang ditentukan oleh pengurus maupun pelatih. Dalam pemenuhan gizi bagi setiap atlet dikembalikan ke masing-masing atlet untuk dapat menjaga pola makan dan kebugarannya dengan mengkonsumsi makanan yang bergizi baik buah maupun sayuran setiap hari. Dan apabila dalam proses pertandingan atlet dapat membawa pulang juara setiap atlet berhak untuk diberikan pengharagaan berupa sertifikat/piagam yang nantinya dapat berguna ketika akan melanjutkan jenjang berikutnya.

4. Sarana dan Prasarana

Dari hasil wawancara di klub Bina Taruna Semarang diperoleh data pada klub Bina Taruna memiliki banyak bola voli, keranjang bola voli, net, cone. Kemudian untuk lapangan belum ada, dalam kegiatan pelatihan, pengurus menyewa GOR Kedungmundu Semarang dengan sistem sewa bulanan.

5. Program Latihan

Volume 2 Nomor 1 Tahun 2021 | 11 
Dari hasil wawancara tentang program latihan bahwa klub Bina Taruna Semarang membuat program latihan fisik maupun tehnik dilakukan seminggu 3 kali pada hari rabu latihan fisik dan hari jumat dan minggu untuk latihan tehnik. Untuk program latihan mental diberikan dengan meningkatkan waktu latihan persahabatan dengan klub-klub yang berada di wilayah Semarang. Berguna untuk meningkatkan mental kepercayaan diri atlet saat bertanding. Pelatih selalu memiliki program latihan yang diterapkan dengan 2 puncak latihan dibulan Juli dan Desember dengan waktu latihan dua kali dalam 1 minggu. Dari hasil latihan pelatih selalu memberikan evaluasi terhadap kemampuan baik kelebihan dan kekurangan atlet diwaktu latihan agar dapat ditingkatkan lagi.

6. Dukungan/Sumber dana

Dari hasil wawancara tentang dukungan atau sumber Dana klub Bina Taruna Semarang bahwa diperoleh dari iuran bulanan siswa dan tambahan iuran dari orang tua atlet jika mengikuti event pertandingan bola voli baik level kota, daerah maupun provinsi.

\section{Prestasi}

Dari hasil wawancara tentang prestasi, prestasi yang diperoleh atlet klub Bina Taruna Semarang adalah Kejuaraan pervis kota semarang juara 1 untuk kelompok umum, juara 2 untuk kelompok SMA, juara 2 untuk U-17, juara 2 untuk U-15 se Kota Semarang.

\section{KESIMPULAN}

Dalam Orgaisasi klub Bina Taruna, sudah ada struktur organisasinya ada Ketua umum, sekretaris, bendahara, bidang ketua harian, bidang kepelatihan, bidang pendanaan dan bidang umum. Kepengurusan pengelolaan klub Bina Taruna Semarang sudah dijalankan dengan baik, sesuai dengan bidangnya masing-masing pengurus, dan saling kerjasama untuk peningkatan klub Bina Taruna Semarang, Perekrutan pelatih klub Bina Taruna Semarang dilakukan oleh pengurus dengan kriteria tertentu minimal mempunyai sertifikat pelatihan pelatih bola voli. Para pelatih klub Bina Taruna Semarang sudah memiliki sertfikat. Kualitas pelatih Klub Bina Taruna Semarang sudah baik karena pelatih klub Bina Taruna memili kualitas dalam sistem pelatihan dan membuat program latihan, Untuk atlet bola voli Bina Taruna Semarang, sudah baik telah mengikuti program latihan secara disiplin sesuai jadwal yang telah ditentukan oleh pengurus maupun pelatih. Untuk jumlah atlet yang mengikuti latihan di klub ini terbagi menjadi dua kategori yaitu yunior putra dan senior putra yang rata-rata jumlah pemainnnya lebih dari 20, Fasilitas sarana dan prasarana sudah dapat dikatakan cukup dan baik untuk menunjang latihan. Sarana dan prasarana olahraga meliputi bola voli, keranjang bola voli, net, alat untuk latihan fisik atlet dan lapangan bola voli walaupun masih sistem menyewa bulanan, Program latihan sudah berjalan 
dengan baik yaitu latihan dua kali dalam seminggu ada juga yang latihan tiga kali dalam seminggu, program latihannya meliputi latihan fisik, latihan mental dan latihan tehnik. Dalam hal tentang dukungan atau pendanaan sudah cukup baik, pendanaannya diperoleh dari iuran bulanan atlet dan iuran dari orang tua atlit jika ada pertandingan, Klub Bina Taruna Semarang mengikuti pertandingan ditingkat daerah, provinsi maupun Nasional.

\section{REFERENSI}

Amin, H., \& Adnan, A. (2020). Studi Tentang Beberapa Komponen Kondisi Fisik Atlet BolaVloi SMK Negeri 1 Kota Solok. Jurnal Patriot Vol 2 No 1 Tahun 2020 ISSN 27146596

Ateng, A. 2013. Pendidikan Olahraga. Jakarta: IKIP Jakarta

Bachtiar, W. B., Budiarto., \& Kastrena, E. 2019. Hubungan Antara Daya Ledak Otot Lengan Dengan Kemampuan SMASH Bola Voli Pada Ekstrakulikuler. Jurnal Maenpo Vol 9 No 1 Tahun 2019

Candrawati, Y., \& Ilahi, B. R. (2018). Evaluasi Program Pembinaan Prestasi Olahraga Bola Voli Pada Smk Negeri Di Kota Bengkulu. Kinestetik: Jurnal Ilmiah Pendidikan Jasmani, 2(1), 4448.

Jamalong, A. (2016). Peningkatan prestasi olahraga nasional secara dini melalui pusat pembinaan dan latihan pelajar
(PPLP) dan pusat pembinaan dan latihan mahasiswa (PPLM). Jurnal Pendidikan Olah Raga Vol 3 No 2 Pages 156-168

Jonasson, Kale (2013). Sport Has Never Been Modern. Gothenburg. Acta Universitatis Gothoburgensis.

Kristiyanto, Agus. 2012. Pembangunan Olahraga untuk Kesejahteraan Rakyat dan Kejayaan Bangsa. Surakarta: Yuma Pustaka.

Moleong, L. J. (2010). Metodologi Penelitian Kualitatif. Bandung: PT Remaja Rosdakarya.

Mutohir, T. C., \& Maksum, A. (2007). Sport Development Index. Jakarta: PT. Indeks.

Siregar, S., Groenwold, R. H., de Heer, F., Bots, M. L., van der Graaf, Y., \& van Herwerden, L. A. (2012). Performance of the original EuroSCORE. European journal of cardio-thoracic surgery, 41(4), 746754.

Subarjah, Herman. (2011). Permainan bulutangkis. Bandung: CV. Bintang Warli Artika.

Suharno HP. (2010). Ilmu Kepelatihan Olahraga. Yogyakarta: FPOK IKIP Yogyakarta

Sugiyono.(2014). Metode Penelitian Pendidikan. Bandung: Alfabeta

Yudiana \& Subroto. 2010. Permainan Bolavoli. Bandung: FPOK Universitas Pendidikan Indonesia 